\title{
rRNA Gene Restriction Patterns as Taxonomic Tools for the Genus Aeromonas
}

\author{
GLADYS MARTINETTI LUCCHINI AND MARTIN ALTWEGG* \\ Institute of Medical Microbiology, University of Zürich, \\ Gloriastrasse 32, 8028 Zürich, Switzerland
}

\begin{abstract}
In the genus Aeromonas there are at least 13 DNA hybridization groups, which are difficult to differentiate biochemically. We investigated the usefulness of rRNA gene restriction patterns for characterization and identification of the various groups. Genomic DNA was digested with restriction endonuclease SmaI, transferred to a nylon membrane, and hybridized with biotinylated plasmid pKK3535 containing the $r r n B$ operon of Escherichia coli. The SmaI bands at 0.8 to $4 \mathrm{~kb}$ but not those at positions corresponding to sizes larger than $4 \mathrm{~kb}$ showed a good correlation with hybridization groups, allowing identification of strains to the level of genetic species. We demonstrated that the 567-bp fragment localized between positions 80 and 647 of the $16 \mathrm{~S}$ ribosomal gene of $E$. coli was essential for hybridization to the low-molecular-weight fragments, whereas the remainder of the operon did not hybridize to these fragments. On the basis of these results, we concluded that the Aeromonas chromosome contains multiple rRNA operons which may be used for species identification.
\end{abstract}

Aeromonas species are ubiquitous aquatic organisms whose role as significant pathogens that cause diarrheal disease is controversial $(2,23)$. Gastrointestinal infections in otherwise healthy persons have been documented, particularly in association with the drinking of untreated water or the consumption of seafood $(3,21)$. Septicemia with Aeromonas sp. is most likely to occur in immunocompromised patients $(14,18)$, and it has been suggested that infections with multiple species or biotypes can occur $(16,24)$. Assessing the clinical significance of Aeromonas species has been greatly hampered by our inability to identify these organisms to the level of genetic species.

Popoff and coworkers (28) differentiated three species of motile mesophilic aeromonads, Aeromonas hydrophila, Aeromonas caviae, and Aeromonas sobria. These species were clearly separable on the basis of a limited number of biochemical characteristics. Since the study of Popoff et al., the following additional species which have distinct phenotypic properties have been described: Aeromonas media, Aeromonas eucrenophila, Aeromonas schubertii, Aeromonas veronii, Aeromonas jandaei, Aeromonas trota, Aeromonas enteropelogenes, and Aeromonas ichthiosmia (10-12, $19,20,30,31$ ). The results of DNA relatedness studies have indicated that within some phenotypic species there are at least two or three distinct hybridization groups (HGs) (i.e., genetic species). HGs are usually identified by using the S1 nuclease method (13) or the hydroxyapatite method (7). However, these methods are laborious, require large amounts of purified DNA, and involve radioactive labeling of DNA. By using a relevant number of phenotypic characteristics and cluster analysis, it has been possible to find a correlation between phenotypic identification and classification based on DNA relatedness, thus providing a partial basis for separation of seven HGs (5).

Determination of rRNA gene restriction (rDNA) fragment polymorphisms has been described previously as a taxonomic tool (17), and this method has been used successfully in molecular epidemiology to differentiate strains of various bacterial species $(1,26,27,33)$.

In this study, ribotyping of restricted genomic DNAs of

\footnotetext{
* Corresponding author.
}

members of various Aeromonas HGs was performed by using different fragments of a 16S rRNA gene of Escherichia coli as probes. The resulting DNA fingerprints were used to identify Aeromonas strains to the level of genetic species.

\section{MATERIALS AND METHODS}

Bacterial strains, plasmids, culture media, and growth conditions. A total of 166 Aeromonas strains were analyzed (Table 1). The collection of strains included strains belonging to known HGs (mostly isolated from human fecal specimens) (5), as well as the definition strain for each group. Strains of $A$. enteropelogenes and $A$. ichtiosmia were not available for analysis. Two strains of Vibrio cholerae and one strain each of Vibrio parahaemolyticus, Vibrio fluvialis, Vibrio alginolyticus, E. coli, Cedecea davisae, Citrobacter freundii, Enterobacter cloacae, Hafnia alvei, Klebsiella pneumoniae, Pseudomonas aeruginosa, Plesiomonas shigelloides, Shigella sonnei, and Yersinia enterocolitica were analyzed for comparison.

E. coli DH5 $\alpha$ (GIBCO-Bethesda Research Laboratories, Gaithersburg, Md.) was used as the recipient in cloning experiments.

Serratia fonticola 3965 DNA (17) was used as a standard molecular size marker in hybridization experiments.

Plasmid pKK3535, which was constructed by cloning the $r m B$ operon of $E$. coli into the BamHI site of pBR322 (9), was used in hybridization and subcloning experiments.

For DNA isolation, bacterial strains were grown overnight in $\mathrm{L}$ broth (29) at $37^{\circ} \mathrm{C}$ with continuous shaking. $E$. coli strains were grown at $37^{\circ} \mathrm{C}$ on $\mathrm{L}$ agar plates or in $\mathrm{L}$ broth, both supplemented with ampicillin $(50 \mu \mathrm{g} / \mathrm{ml})$.

DNA isolation and hybridization. Total genomic DNA was extracted by using a standard miniprep procedure (6), and aliquots $(5 \mu \mathrm{g})$ were digested to completeness with SmaI (Boehringer Mannheim, Mannheim, Germany) as recommended by the manufacturer. Fragments were separated in a $1.2 \%$ agarose gel in TBE buffer $(0.089 \mathrm{M}$ Tris, $0.089 \mathrm{M}$ boric acid, $0.2 \mathrm{mM}$ EDTA; pH 8.0), stained with ethidium bromide, and transferred to a nylon membrane (BiodyneA; Pall Biosupport, East Hills, N.Y.) by using the method of Southern (32).

Intact plasmid pKK3535 was purified by cesium chloride- 
TABLE 1. Aeromonas strains $^{a}$

\begin{tabular}{|c|c|c|c|}
\hline $\begin{array}{l}\text { DNA } \\
\mathrm{HG}^{b}\end{array}$ & $\begin{array}{l}\text { Total } \\
\text { no. of } \\
\text { strains }\end{array}$ & $\begin{array}{l}\text { Definition } \\
\text { strain }^{c}\end{array}$ & Comment(s) \\
\hline 1 & 36 & ATCC $7966^{\mathrm{T}}$ & Phenotypically $A$. hydrophila \\
\hline 2 & 10 & CDC 9533-76 & Phenotypically $A$. hydrophila \\
\hline 3 & 10 & CDC 0434-84 & $\begin{array}{l}\text { Phenotypically } A \text {. hydrophila; pheno- } \\
\text { typically } A \text {. salmonicida strains, } \\
\text { which belong to the same HG, } \\
\text { were not tested }\end{array}$ \\
\hline 4 & 30 & ATCC $15468^{\mathrm{T}}$ & Phenotypically $A$. caviae \\
\hline $5 \mathrm{~A}$ & 14 & CDC 0862-83 & Phenotypically $A$. caviae \\
\hline 5B & 7 & CDC 0435-84 & $\begin{array}{l}\text { Phenotypically } A \text {. caviae; this group } \\
\text { contains the type strain of } A . m e- \\
\text { dia (not tested) }\end{array}$ \\
\hline 6 & 2 & ATCC 23309 & A. eucrenophila \\
\hline 7 & 2 & CDC $9538-76$ & Phenotypically $A$. sobria \\
\hline $8^{d}$ & 36 & CDC $0437-84$ & Phenotypically $A$. sobria \\
\hline 9 & 4 & CDC $0787-80$ & Phenotypically $A$. jandaei \\
\hline $10^{d}$ & 7 & ATCC $35624^{\mathrm{T}}$ & Phenotypically $A$. veronii \\
\hline 11 & 2 & CDC $1306-83$ & Phenotypically similar to $A$. veronii \\
\hline 12 & 2 & ATCC 43700 & Phenotypically $A$. schubertii \\
\hline 13 & 4 & ATCC 49657 & Phenotypically $A$. trota \\
\hline
\end{tabular}

${ }^{a} A$. enteropelogenes and $A$. ichtiosmia strains were not available for analysis.

${ }^{b}$ HGs are listed in references 5 and 22.

c CDC, Centers for Disease Control, Atlanta, Ga.; ATCC, American Type Culture Collection, Rockville, Md.; T = type strain.

${ }^{d}$ HGs 8 and 10 are identical, although different biotypes are known to exist (22).

ethidium bromide gradient centrifugation and was labeled by nick translation, using biotin-11-dUTP (GIBCO-Bethesda Research Laboratories). Standard protocols were used for hybridizations (29). Hybrids were visualized by using a BluGene kit (GIBCO-Bethesda Research Laboratories).

Plasmid pKK3535 was digested with BamHI. Bands representing single restriction fragments were excised from a $0.8 \%$ low-melting-point agarose gel (FMC BioProducts, Rockland, Maine), and the DNA was purified by using Geneclean (Bio 101, Inc., La Jolla, Calif.). The 7.5-kb fragment which we obtained (Fig. 1), which contained the entire $r m B$ operon, was also digested with BstEII or HindIII, and fragments were separated and purified as described above. Fragments were labeled with $\left[\gamma-{ }^{32} \mathrm{P}\right] \mathrm{dCTP}$ (Amersham International, Buckinghamshire, England) by using a random primer labeling kit (Boehringer Mannheim) according to the instructions provided by the manufacturer. Hybrids were detected by autoradiography at room temperature, using type NiF RX film (Fuji Photo Film Co., Ltd.).

Construction of pGML1. Plasmid pKK3535 was digested with HindIII, and the 567-bp fragment corresponding to nucleotides 80 to 647 of the 16S rRNA operon (Fig. 1) was purified as described above. This fragment was ligated with vector pGEM11zf(+) (Promega, Madison, Wis.), which had been linearized with HindIII and treated with calf alkaline phosphatase. Competent cells of $E$. coli DH5 $\alpha$ were transformed with the ligated plasmid and plated onto $\mathbf{L}$ agar supplemented with 5-bromo-4-chloro-3-indolyl- $\beta$-D-galactopyranoside, isopropyl- $\beta$-D-thiogalactopyranoside, and ampicillin (29). The plasmid was purified on white $E$. coli colonies that were grown on a selective medium, and the identity of the cloned fragment was determined by restriction enzyme analysis.

\section{RESULTS}

Plasmid pKK3535 hybridized with low- and high-molecular-weight fragments of SmaI-digested total genomic DNAs from the strains which we used (data not shown). A very high level of diversity of rDNA patterns was observed; the greatest diversity occurred among the high-molecular-weight bands (20 to $4.3 \mathrm{~kb}$ ), whereas the low-molecular-weight bands ( 4 to $0.8 \mathrm{~kb}$ ) were more conserved. A $0.8-\mathrm{kb}$ DNA band was present in all of the Aeromonas strains analyzed, as well as in $V$. parahaemolyticus, $V$. fluvialis, $V$. alginolyticus, E. coli, Cedecea davisae, Citrobacter freundii, Enterobacter cloacae, $H$. alvei, $K$. pneumoniae, and Shigella sonnei. This fragment was absent in the Serratia fonticola strain used as a standard, as well as in Pseudomonas aeruginosa, $V$. cholerae, Plesiomonas shigelloides, and $Y$. enterocolitica (data not shown).

In order to determine which fragment of pKK3535 was responsible for the hybridization to low-molecular-weight bands, various restriction fragments of pKK3535 were used as probes (Fig. 1). The low-molecular-weight bands were not detected when we used the 4.5-kb BstEII-BamHI fragment as a probe. This fragment contained the genes for tRNAGlu and $23 \mathrm{~S}$ and $5 \mathrm{~S}$ rRNAs (Fig. 2A). The low-molecular-weight rDNA bands observed after hybridization with the $3-\mathrm{kb}$ Bam HI-BstEII fragment containing the 16S rRNA gene (Fig. 2B) were identical to those observed after hybridization with the entire plasmid. This fragment was further digested with

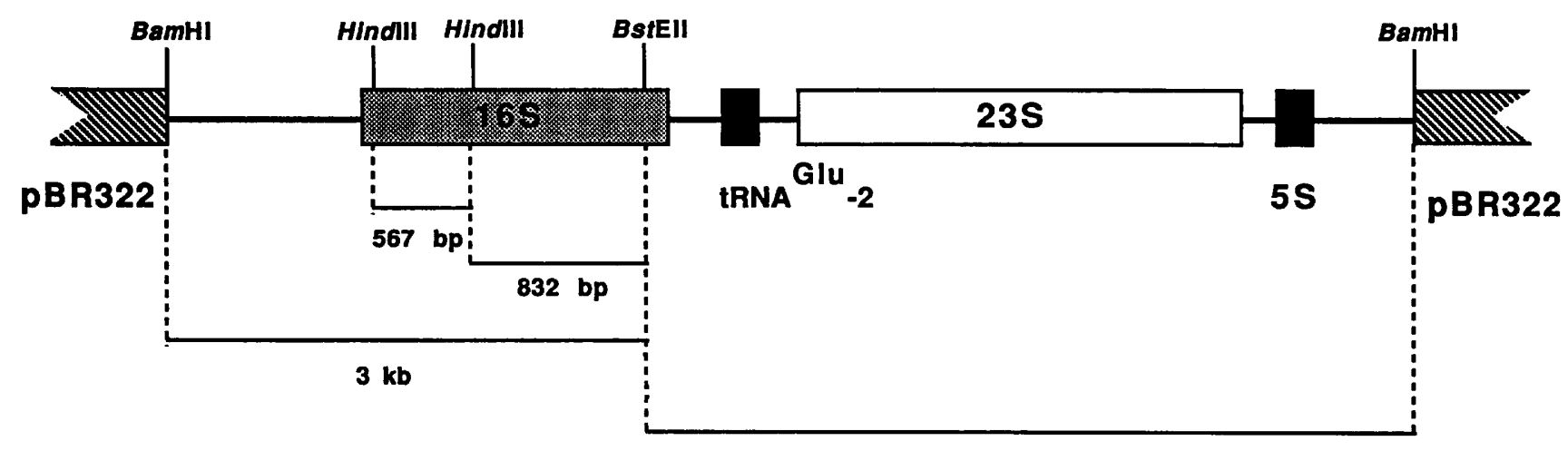

$4.5 \mathrm{~kb}$

FIG. 1. Partial restriction map of the DNA insertion of plasmid pKK3535 containing the $r m B$ operon of $E$. coli. The lengths of the fragments used in this study are indicated. 

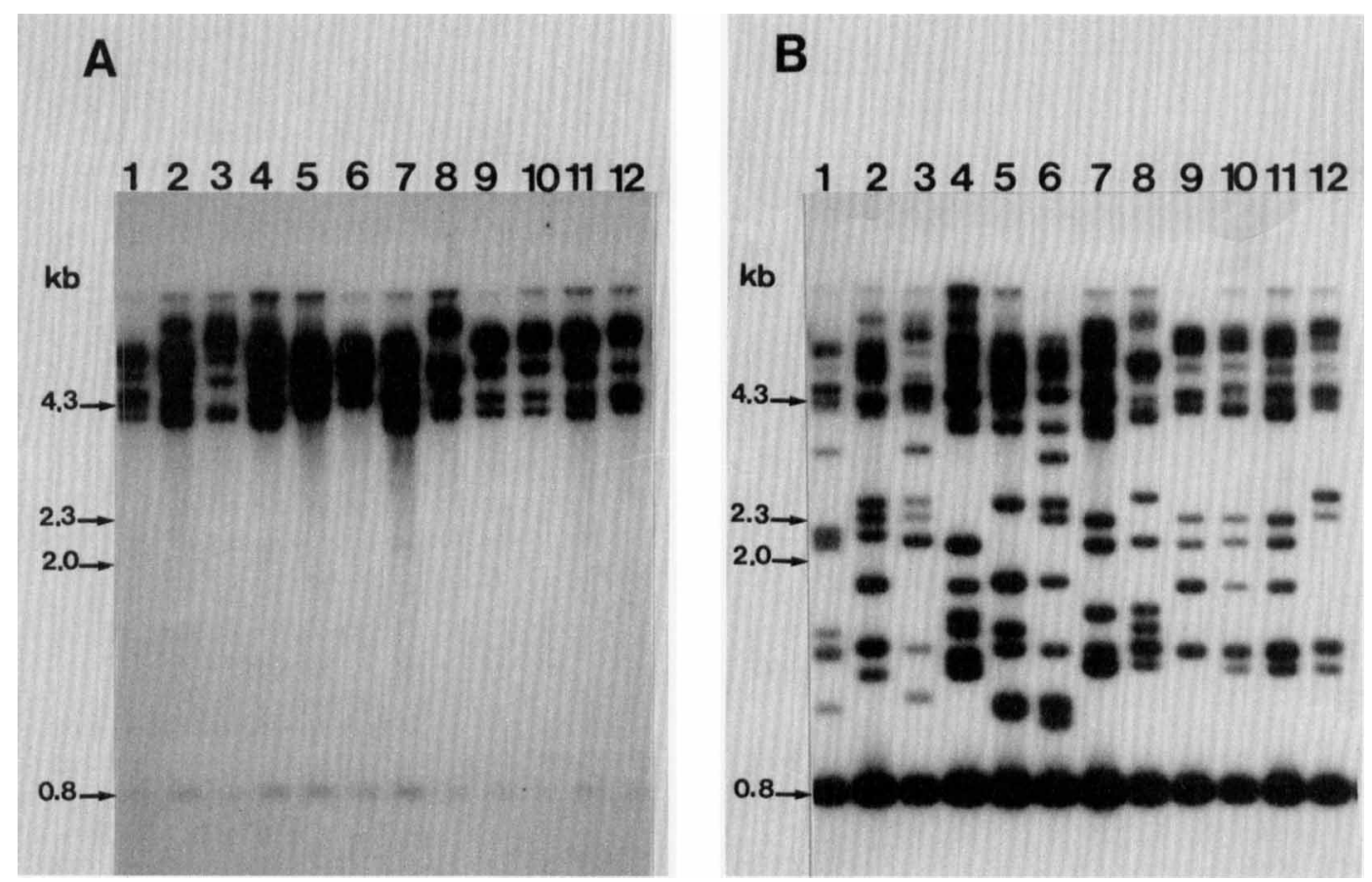

FIG. 2. Autoradiogram of genomic DNAs of Aeromonas spp. strains digested with $S m a$ I and hybridized with the 4.5-kb BstEII-BamHI fragment of pKK 3535 (A) and with the 3-kb BamHI-BstEII fragment of pKK3535 (B). Lanes 1 through 4, strains belonging to HGs 1 through 4, respectively; lanes 5, HG 5A strain; lanes 6, HG 5B strain; lanes 7, HG 6 strain; lanes 8, HG 7 strain; lanes 9 through 12, HG 8 strains.

HindIII, and only the internal 567-bp HindIII fragment (and not the 832-bp HindIII-BstEII fragment) hybridized with all of the low-molecular-weight bands. However, hybridization with the 800 -bp band, which was common to all of the HGs, was stronger with the 832-bp HindIII-BstEII fragment than with the 567-bp HindIII fragment.

The 567-bp HindIII fragment was cloned into plasmid pGEM11zf(+), which did not hybridize with genomic DNA sequences of Aeromonas spp. (data not shown), and the resulting plasmid, plasmid pGML1, was used for further investigations. The numbers of high-molecular-weight bands that hybridized with pGML1 ranged from two to five, and highly variable patterns were observed (Fig. 3). However, the low-molecular-weight bands had distinct patterns which were highly correlated with the different HGs. With the exception of the 800-bp band described above, we did not find bands that were common to all of the groups analyzed in this study.

We calculated the frequency with which the various low-molecular-weight bands complementary to pGML1 were found in the different HGs (Fig. 4). In each group there were at least two bands which occurred in every strain. In addition, some of these bands were not found in any strain belonging to a different $\mathrm{HG}$ and could therefore be considered to be species (or HG) specific.

For strains that were phenotypically $A$. hydrophila (HGs 1 through 3 ), there were several bands at positions corresponding to sizes smaller than $2.0 \mathrm{~kb}$ which were specific for one of the three HGs (Fig. 4) and thus allowed easy separation of the strains. Three $A$. hydrophila strains belonging to $\mathrm{HG} 1$ were excluded from this analysis because of questionable assignment to this HG by the rDNA analysis (see Discussion).

Discrimination within the strains that were phenotypically
A. caviae (HGs 4, 5A, and 5B) could also be achieved on the basis of the presence or absence of bands found in all of the strains of a group. However, the positions of some of these bands were very similar (for example, the double band at about 1 to $1.2 \mathrm{~kb}$ present in HGs $5 \mathrm{~A}$ and $5 \mathrm{~B}$ ), and therefore, the bands could be distinguished only when they were analyzed in adjacent lanes on a gel.

HGs 7 and 8 (strains that were phenotypically $A$. sobria) could be separated on the basis of one band at about $2.2 \mathrm{~kb}$ which was present in both HG 7 strains but in none of the 36 HG 8 strains, as well as on the basis of several bands at about $1.8 \mathrm{~kb}$. The pattern for the seven strains of HG $10(A$. veronii biogroup veronii) was indistinguishable from the pattern for HG 8. Only the frequency (not the position) of the single bands varied between the members of these two HGs. HGs 6 (A. eucrenophila), 11 (A. veronii-like), and 12 (A. schubertii) were represented by only a very few strains. All three of these groups were characterized by their unique and invariable $16 \mathrm{~S}$ rDNA patterns.

\section{DISCUSSION}

By using hybridization of SmaI-digested Aeromonas DNAs with a plasmid containing an rRNA operon of $E$. coli, we detected a broad spectrum of low- and high-molecularweight bands. In previous studies in which restriction fragment analysis and rDNA typing of Aeromonas strains have been used, workers have reported high degrees of variability in patterns and excellent discrimination between strains that are not related epidemiologically. However, the low-molecular-weight bands after hybridization were not visible (25) or were very faint (1), and therefore, only the high-molecularweight bands were considered. We identified a DNA frag- 


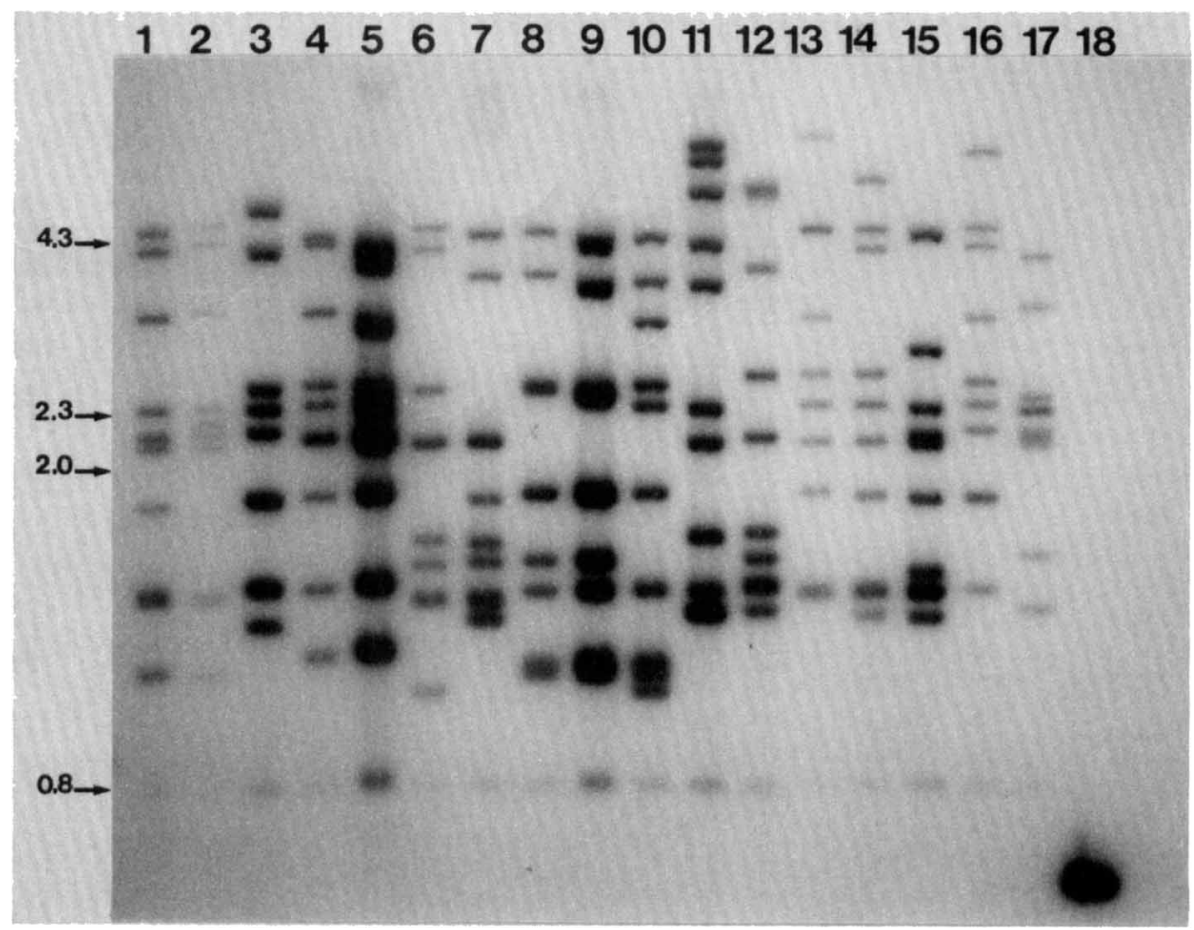

FIG. 3. Autoradiogram of genomic DNAs of Aeromonas spp. strains digested with SmaI and hybridized with plasmid pGML1. Lanes 1 and 2, HG 1 strains; lane 3, HG 2 strain; lanes 4 and 5, HG 3 strains; lanes 6 and 7, HG 4 strains; lanes 8 and 9, HG 5A strains; lane 10, HG 5B strain; lane 11, HG 6 strain; lane 12, HG 7 strain; lanes 13 and 14, HG 8 strains; lane 15, HG 9 strain; lanes 16 and 17, strains belonging to HG 11 and 12, respectively; lane 18, 567-bp HindIII fragment of the 16S rRNA gene of $E$. coli.

ment that spanned the $5^{\prime}$ end of the $16 \mathrm{~S}$ rRNA gene and produced Aeromonas genospecies-specific patterns. The lengths of the fragments were defined by $S$ mal sites located upstream from the 16S rRNA genes since the low-molecularweight fragments did not contain sequences that were complementary to other parts of the $16 \mathrm{~S}$ rRNA. Coupled with the fact that these fragments were larger than the probe which we used, our results suggested that Aeromonas strains contain six to eight rRNA operons dispersed on the chromosome. This is similar to what has been observed in other bacteria, as indicated by the report of Ellwood and Nomura (15), who completed the mapping of seven rRNA operons in $E$. coli $\mathrm{K}-12$. The 800 -bp band found in all of the strains which we studied is most likely an internal fragment of the 16S rRNA gene. In the $r m B$ operon of $E$. coli (8), a 770-bp SmaI fragment is located between nucleotides 613 and 1383 and shares 34 nucleotides with the HindIII fragment and 736 bp with the HindIII-BstEII fragment. We do not know which factors are responsible for the higher intensities of the low-molecular-weight bands in this study compared with previous studies. Presumably, several variables, such as the quality of the membrane or the probe-labeling method, may have contributed to this phenomenon.

In order to perform a quantitative analysis of the hybridization patterns, we tried to assign a distinct number to each band according to the mobility of the band in the gel. However, because of the high number of different bands detected in the $12 \mathrm{HGs}$, this was not possible, and unequivocal identification of each band was very difficult or even impossible. Therefore, we based our discrimination of the 12 HGs on a qualitative evaluation of patterns by checking for distinct bands that were typical for each HG. A few bands that were always found in some DNA HGs and were always absent in others allowed reliable identification of genetic species. It was also possible to detect abnormal patterns for three strains that had been placed in HG 1 by using the hydroxyapatite method. In one of these strains (strain A34) we observed a pattern that best fit in HG 4. This strain was in fact assigned to HG 4 by using multilocus enzyme electrophoresis, although the DNA-DNA homology data were unequivocal (100 and $90 \%$ levels of homology with the definition strain of DNA HG 1 at 60 and $75^{\circ} \mathrm{C}$, respectively, and a $\Delta T_{m}$ of $1^{\circ} \mathrm{C}\left[\Delta T_{m}\right.$ is the difference between the melting point of a homologous hybrid and the melting point of a heterologous hybrid]) (4). The patterns of the low-molecularweight bands of the two other strains of $A$. hydrophila (strains A906 and A907) were identical but exhibited the typical pattern of HG 1 only in the lower bands (first double band from the bottom). These strains also exhibited a low level of phenotypic relationship with the majority of the strains in DNA HG 1 in a cluster analysis of the results of multilocus enzyme typing (4). In addition, two $A$. caviae strains (strains A58 and A89) which could not previously be assigned to HG $5 \mathrm{~A}$ or $5 \mathrm{~B}$ on the basis of DNA hybridization data clearly fell into HG 5A when our procedure was used. For some of the rare DNA HGs only a few strains were available, and therefore, the results for these groups should be interpreted carefully.

In conclusion, we developed a molecular method which allows identification of most Aeromonas strains to the level of genetic species. This method is much easier than DNADNA hybridization because only minimal amounts of genomic DNA are needed and because several strains can be analyzed on a single gel. 


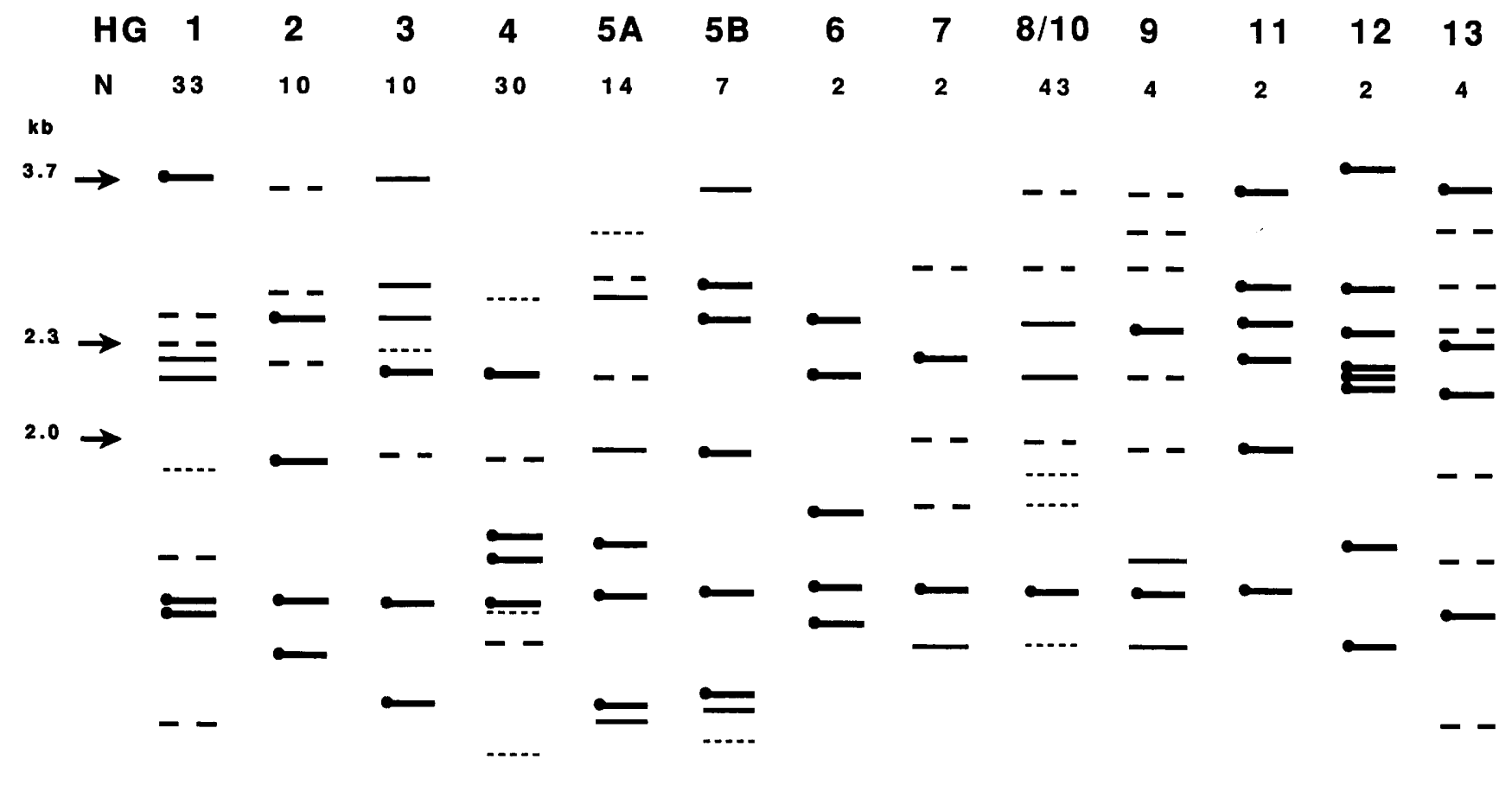

0.8

FIG. 4. Schematic representation of the low-molecular-weight DNA patterns detected after hybridization with plasmid pGML1. The frequency of each band (as a percentage) was calculated, and the frequencies are indicated as follows: $\leftarrow$ - $100 \%$;,- 85 to $99 \%$; ,-- 84 to $20 \% ;-----,<20 \%$. The positions of molecular weight markers are indicated by arrows. Abbreviation: $\mathrm{N}$, number of strains analyzed.

\section{ACKNOWLEDGMENTS}

We are grateful to C. Ryffel and A. von Graevenitz for critical examination of the manuscript.

\section{REFERENCES}

1. Altwegg, M., R. Altwegg-Bissig, A. Demarta, R. Peduzzi, M. W. Reeves, and B. Swaminathan. 1988. Comparison of four typing methods for Aeromonas species. J. Diarrhoeal Dis. Res. 6:8894.

2. Altwegg, M., and H. K. Geiss. 1989. Aeromonas as human pathogen. Crit. Rev. Microbiol. 16:253-286.

3. Altwegg, M., G. Martinetti Lucchini, J. Luethy-Hottenstein, and M. Rohrbach. 1991. Aeromonas-associated gastroenteritis after consumption of contaminated shrimp. Eur. J. Clin. Microbiol. Infect. Dis. 10:44.

4. Altwegg, M., M. W. Reeves, R. Altwegg-Bissig, and D. J. Brenner. 1991. Multilocus enzyme analysis of the genus Aeromonas and its use for species identification. Zentralbl. Bakteriol. 275:28-45.

5. Altwegg, M., A. G. Steigerwalt, R. Altwegg-Bissig, J. LüthyHottenstein, and D. J. Brenner. 1990. Biochemical identification of Aeromonas genospecies isolated from humans. J. Clin. Microbiol. 28:258-264.

6. Ausubel, F. M., R. Brent, R. E. Kingston, D. D. Moore, J. G. Seidman, J. A. Smith, and K. Struhl. 1989. Current protocols in molecular biology. John Wiley and Sons, Chichester, United Kingdom.

7. Brenner, D. J. 1978. Characterization and clinical identification of Enterobacteriaceae by DNA hybridization. Prog. Clin. Pathol. 7:71-117.

8. Brosius, J., M. L. Palmer, P. J. Kennedy, and H. F. Noller. 1978. Complete nucleotide sequence of a $16 \mathrm{~S}$ ribosomal RNA gene from Escherichia coli. Proc. Natl. Acad. Sci. USA 75:48014805.

9. Brosius, J., A. Ullrich, M. A. Raker, A. Gray, T. J. Dull, R. R. Gutell, and H. F. Noller. 1981. Construction and fine mapping of recombinant plasmids containing the $r m B$ ribosomal RNA operon of $E$. coli. Plasmid 6:112-118.

10. Carnahan, A., G. R. Fanning, and S. W. Joseph. 1991. Aeromonas jandaei (formerly genospecies DNA group 9 A sobria), a new sucrose-negative species isolated from clinical specimens. J. Clin. Microbiol. 29:560-564.

11. Carnahan, A. M., T. Chakraborty, G. R. Fanning, D. Verma, A. Ali, J. M. Janda, and S. W. Joseph. 1991. Aeromonas trota sp. nov., an ampicillin-susceptible species isolated from clinical specimens. J. Clin. Microbiol. 29:1206-1210.

12. Carnahan, A. M., M. A. Marii, G. R. Fanning, M. A. Pass, and S. W. Joseph. 1989. Characterization of Aeromonas schubertii strains recently isolated from traumatic wound infections. J. Clin. Microbiol. 27:1826-1830.

13. Crosa, J. H., D. J. Brenner, and S. Falkow. 1973. Use of single-strand-specific nuclease for analysis of bacterial and plasmid deoxyribonucleic acid homo- and heteroduplexes. J. Bacteriol. 115:904-911.

14. Dryden, M., and R. Munro. 1989. Aeromonas septicemia: relationship of species and clinical features. Pathology 21:111114.

15. Ellwood, M., and M. Nomura. 1982. Chromosomal locations of the genes for rRNA in Escherichia coli K-12. J. Bacteriol. 149:458-468.

16. Gray, S. J., and A. Griffiths. 1990. Observations on Aeromonas species isolated from human faeces. J. Infect. 20:267-268.

17. Grimont, F., and P. A. D. Grimont. 1986. Ribosomal ribonucleic acid gene restriction patterns as potential taxonomic tools. Ann. 
Inst. Pasteur/Microbiol. (Paris) 137B:165-175.

18. Harris, R. L., V. Fainstein, L. Elting, R. L. Hopfer, and G. P. Bodey. 1985. Bacterimia caused by Aeromonas sp. in hospitalized cancer patients. Rev. Infect. Dis. 7:314-320.

19. Hickman-Brenner, F. W., G. R. Fanning, M. J. Arduino, D. J. Brenner, and J. J. Farmer III. 1988. Aeromonas schubertii, a new mannitol-negative species found in human clinical specimens. J. Clin. Microbiol. 26:1561-1564.

20. Hickman-Brenner, F. W., K. L. MacDonald, A. G. Steigerwalt, G. R. Fanning, D. J. Brenner, and J. J. Farmer III. 1987. Aeromonas veronii, a new ornithine decarboxylase-positive species that may cause diarrhea. J. Clin. Microbiol. 25:900-906.

21. Holmberg, S. D., W. D. Schell, G. R. Fanning, I. K. Wachsmuth, F. W. Hickman-Brenner, P. A. Blake, D. J. Brenner, and J. J. Farmer III. 1986. Aeromonas intestinal infections in the United States. Ann. Intern. Med. 105:683-689.

22. Janda, J. M. 1991. Recent advances in the study of the taxonomy, pathogenicity, and infectious syndromes associated with the genus Aeromonas. Clin. Microbiol. Rev. 4:397-410.

23. Janda, J. M., and P. S. Duffey. 1988. Mesophilic aeromonads in human disease: current taxonomy, laboratory identification, and infectious disease spectrum. Rev. Infect. Dis. 10:980-997.

24. Joseph, S. W., A. M. Carnahan, P. R. Brayton, G. R. Fanning, R. Almazan, C. Drabick, E. W. Trudo, Jr., and R. R. Colwell. 1991. Aeromonas jandaei and Aeromonas veronii dual infection of a human wound following aquatic exposure. J. Clin. Microbiol. 29:565-569.

25. Kuijper, E. J., L. van Alphen, E. Leenders, and H. C. Zanen.
1989. Typing of Aeromonas strains by DNA restriction endonuclease analysis and polyacrylamide gel electrophoresis of cell envelopes. J. Clin. Microbiol. 27:1280-1285.

26. Martinetti, G., and M. Altwegg. 1990. rRNA gene restriction patterns and plasmid analysis as a tool for typing Salmonella enteritidis. Res. Microbiol. 141:1151-1162.

27. Morgan, D. D., and R. J. Owen. 1990. Use of DNA restriction endonuclease digest and ribosomal RNA gene probe patterns to fingerprint Helicobacter pylori and Helicobacter mustelae isolated from human and animal hosts. Mol. Cell. Probes 4:321334.

28. Popoff, M. J., C. Coynault, M. Kiredjian, and M. Lamelin. 1981. Polynucleotide sequence relatedness among motile Aeromonas species. Curr. Microbiol. 5:109-114.

29. Sambrook, J., E. F. Fritsch, and T. Maniatis. 1989. Molecular cloning, a laboratory manual, 2nd ed. Cold Spring Harbor Laboratory Press, Cold Spring Harbor, N.Y.

30. Schubert, R. H. W., M. Hegazi, and W. Wahlig. 1990. Aeromonas enteropelogenes species nova. Hyg. Med. 15:471-472.

31. Schubert, R. H. W., M. Hegazi, and W. Wahlig. 1990. Aeromonas ichtiosmia species nova. Hyg. Med. 15:477-479.

32. Southern, E. M. 1975 . Detection of specific sequences among DNA fragments separated by electrophoresis. J. Mol. Biol. 98:503-517.

33. Stull, T. L., J. J. Lipuma, and T. D. Edlind. 1988. A broadspectrum probe for molecular epidemiology of bacteria: ribosomal RNA. J. Infect. Dis. 157:280-286. 